\title{
Modulation of Cone Horizontal Cell Activity in the Teleost Fish Retina. I. Effects of Prolonged Darkness and Background Illumination on Light Responsiveness
}

\author{
X.-L. Yang, ${ }^{a}$ K. Tornqvist, ${ }^{b}$ and J. E. Dowling \\ Department of Cellular and Developmental Biology, Harvard University, Cambridge, Massachusetts 02138
}

The effects of prolonged ( $>2 \mathrm{hr}$ ) darkness and background illumination on the light responsiveness of cone horizontal cells were examined in isolated, superfused white perch retinas. In retinas from fish maintained in complete darkness for more than $\mathbf{2} \mathbf{~ h r}$, cone horizontal cells had a resting membrane potential of about $-18 \mathrm{mV}$, and they generated only slow, low-amplitude (3-4 mV) responses even when stimulated with bright flashes. Following the presentation of dim background light, the cone horizontal cells slowly hyperpolarized and thereafter remained at a more hyperpolarized level (about $-25 \mathrm{mV}$ ). Concurrently, their light responses were dramatically enhanced in size, and response amplitudes to bright flashes eventually increased to about $50 \mathrm{mV}$. This was accompanied by noticeable changes in response waveforms; following light exposure, the responses became faster and showed initial on-transients. The increase in cone horizontal cell responsiveness was graded with intensity of the background light. A similar enhancement in response amplitudes of cone horizontal cells occurred after presenting bright flashes repetitively at intervals of 9 sec. This background sensitization phenomenon was observed in both Land C-type cone horizontal cells.

When light-sensitized isolated retinas were maintained in darkness for long periods (>30 $\mathbf{~ m i n}$ ), the light responsiveness of cone horizontal cells gradually decreased. The changes in membrane potential and response waveform were opposite to those that occurred when prolonged dark-adapted retinas were exposed to background lights; the cells depolarized by 5-7 $\mathrm{mV}$ and light-evoked responses became slower.

Effects of background illumination on rod-driven horizontal cells were examined as well. Rod horizontal cells were about 2 log units more sensitive to white light than were cone horizontal cells. When recorded in prolonged dark-adapted

\footnotetext{
Received Apr. 27, 1987; revised Oct. 21, 1987; accepted Oct. 26, 1987.

We are grateful to Ms. S. Levinson for the typing of the manuscript and to Ms. $P$. Sheppard for the preparation of the figures. This research was supported by grants from the National Institutes of Hcalth EY 00824 and EY 00811 . K. T. was supported by the Swedish Medical Research Council (Projects B86-14R-7450; 14X-2321); The Helfrid and Lorenz Nilssons Foundation; The Swedish Institute; The Swedish Society of Medicine; the Fulbright Commission, Stockholm, Sweden; Carin Sandqvist Foundation; and the Faculty of Medicine, University of Lund, Lund, Sweden.

Correspondence should be addressed to John E. Dowling at the above address.

a Present address: Shanghai Institute of Physiology, Academica Sinica, Shanghai, People's Republic of China.

b Present address: Department of Ophthalmology, University of Lund, Lund, Sweden.

Copyright (C) 1988 Society for Neuroscience $0270-6474 / 88 / 072259-10 \$ 02.00 / 0$
}

retinas, rod horizontal cells showed large responses $(\sim \mathbf{5 0}$ $\mathrm{mV}$ ), which could not be further enhanced by background illumination.

Cone horizontal cell responsiveness in the carp retina was also depressed by prolonged darkness and increased by illumination in a fashion similar to that observed in the white perch retina. The change in response amplitude was only about 2-fold in carp compared with 5- to 10-fold changes observed in white perch. These results indicate that the light responsiveness of cone horizontal cells in the teleost retina is suppressed in prolonged darkness and that background lights release the cells from suppression. We conclude that cone horizontal cells require background illumination to maintain high light responsiveness and propose that this phenomenon may be a general one in vertebrate retinas.

Most vertebrate retinas contain 2 types of photoreceptors, rods and cones, which process visual information at different levels of ambient illumination. Rods mediate dim light vision, while cones are responsible for bright light and color vision. It has long been known that rods remain saturated when ambient illumination exceeds certain levels, and thus they cannot contribute to vision under these circumstances. On the other hand, cones and cone pathways are generally thought to remain functional at all levels of illumination, even in complete darkness. In recent years, however, several studies have shown that cone pathways in the teleost fish are depressed when an animal or retina is left in the dark for prolonged periods of time $(>1 \mathrm{hr})$ and that responsiveness of the cone system returns following illumination of the retina. The first of these studies was carried out by Reynauld et al. (1979), who reported that the doubleopponcnt ganglion cells in the goldfish lost color opponency within 1 hr of dark adaptation and became entirely unresponsive during the next $2 \mathrm{hr}$. Normal responses could be restored to these cells by illuminating the retina with a background light for a few minutes.

Subsequently Yang et al. (1982a) studied long-term dark adaptation in goldfish horizontal cells that receive input exclusively from cones. They recorded intracellularly from an opened eye of an intact, immobilized fish. They found that the responses of the L-type cone horizontal cells to full-field illumination increased in amplitude for approximately $20 \mathrm{~min}$ after the beginning of dark adaptation, but they then decreased significantly in amplitude-to $10-20 \%$ of earlier values - when the preparation was left in the dark for more than $1 \mathrm{hr}$. Further, they showed that dim background illumination restored the light responsiveness of the cone horizontal cells to control levels, i.e., 
to the maximal amplitude levels observed after about $30 \mathrm{~min}$ of dark adaptation.

More recently, Mangel and Dowling (1985, 1987) reportcd that the responses of cone horizontal cells to full field stimuli, recorded from carp retinas isolated from animals dark-adapted for roughly $2 \mathrm{hr}$, were only about $40 \%$ the amplitude of horizontal cell responses recorded from retinas isolated from animals dark-adapted for just $30-40 \mathrm{~min}$. In addition, the amplitudes of responses to small spot stimuli $(<1.6 \mathrm{~mm})$ were increased in horizontal cells from retinas of prolonged dark-adapted animals compared with the responses of horizontal cells to the same stimuli in retinas of short-term, dark-adapted retinas. They concluded that prolonged darkness produces 2 effects on horizontal cells: a decreased responsiveness to light and a constriction of the cell's receptive fields. These changes in horizontal cell responses produced by prolonged darkness closely resemble the changes in horizontal cell responses induced when dopamine is applied to the teleost retina, and they suggested that the alterations in horizontal cell responses induced by prolonged darkness may be caused by the release of endogenous dopamine.

In the teleost retina, cone horizontal cells receive direct synaptic input not only from photoreceptors but also from interplexiform cells, neurons whose perikarya are located among the amacrine cells and which send processes to the outer plexiform layer where they make numerous synapses onto the cone horizontal cells (Dowling and Ehinger, 1975, 1978). In teleosts one type of interplexiform cells uses dopamine as a neurotransmitter (Ehinger et al., 1969; Chino and Hashimoto, 1985), and this catecholamine has been shown to suppress the light responsiveness of cone horizontal cells as well as to uncouple them electrically from one another (Hedden and Dowling, 1978; Negishi and Drujan, 1978; Teranishi et al., 1983, 1984; Hankins and Ruddock, 1984; Lasater and Dowling, 1985). These observations suggest that the interplexiform cells and dopamine are involved in the modulation of cone horizontal cell activity by prolonged darkness.

In this series of papers we describe the effects of prolonged darkness and background illumination on the activity of rod and cone horizontal cells in the white perch retina and examine the hypothesis that the dopaminergic interplexiform cells in the retina mediate the observed changes. We have found that prolonged darkness dramatically alters the light responsiveness and electrical coupling of cone horizontal cells in the white perch retina, making this preparation an ideal one in which to study these phenomena. The results suggest that the interplexiform cells and dopamine mediate most of the changes induced in horizontal cells by prolonged darkness, and they indicate that this system may provide a model of neuromodulation in the vertebrate brain. In this first paper we show how the light responsiveness of cone horizontal cells is regulated by prolonged darkness and by background illumination.

\section{Materials and Methods}

Preparation. White perch (Roccus americana) 10-20 cm long, caught in Oyster Pond, Falmouth, MA, were maintained in aerated aquaria on a $12: 12 \mathrm{hr}$ light:dark cycle at approximately $19^{\circ} \mathrm{C}$. Prior to an experiment the fish were dark-adapted for a minimum of $2 \mathrm{hr}$. Unless otherwise specified, retinas from these animals will be referred to as prolonged dark-adapted preparations. The eyes were enucleated and hemisected, and the opened eye cups inverted onto Millipore filters. The retina was carefully separated from the pigment epithelium and placed receptor side up in a superfusion chamber, $1.4 \mathrm{~cm}$ in diameter with a volume of $0.5 \mathrm{ml}$. All of the procedures were performed under dim red light. The superfusion techniques have been previously described (Mangel and Dowling, 1987). Briefly, the superfusion medium that flowed over the isolated retina was delivered to the chamber via fine polyethyline tubing and was drained out by tissue paper placed on the edge of the chamber. The composition of the superfusion medium included: 145 $\mathrm{mm} \mathrm{NaCl}, 2.5 \mathrm{~mm} \mathrm{KCl}, 20 \mathrm{~mm} \mathrm{NaHCO}, 20 \mathrm{~mm}$ glucose, $0.7 \mathrm{~mm} \mathrm{CaCl}_{2}$, and $0.1 \mathrm{mM} \mathrm{MgSO}_{4}$. This solution was continuously bubbled with a mixture of $97 \% \mathrm{O}_{2}$ and $3 \% \mathrm{CO}_{2}$, thus keeping the $\mathrm{pH}$ at 7.7 . Under these conditions the retina functioned normally for more than $5 \mathrm{hr}$, as judged by the electroretinogram and responses of horizontal cells. Some experiments were conducted on retinas from fish kept in darkness for only $20 \mathrm{~min}$. These served as control or short-term dark-adapted preparations.

Some experiments were also performed on superfused carp retinas (Cyprinus carpio). The isolation and superfusion procedures were the same as described for the white perch. The Ringer's solution used for the carp experiments contained: $110 \mathrm{~mm} \mathrm{NaCl}, 2.5 \mathrm{~mm} \mathrm{KCl}, 20 \mathrm{~mm}$ $\mathrm{NaHCO}_{3}, 20 \mathrm{~mm}$ glucose, $0.1 \mathrm{~mm} \mathrm{CaCl}$, and $0.1 \mathrm{~mm} \mathrm{MgSO}_{4}$. It was bubbled with a mixture of $97 \% \mathrm{O}_{2}$ and $3 \% \mathrm{CO}_{2}$ and maintained at $\mathrm{pH}$ 7.6 (Mangel and Dowling, 1985, 1987).

Intracellular recording system. Glass micropipettes, used for intracellular recordings, were made with a modified Livingston-type puller and filled with $4 \mathrm{~m}$ potassium acetate. Their resistances, measured in the superfusion medium, were 70-120 M . Cell penetration was facilitated by transiently oscillating the preamplifier circuit. The recording micropipettes were connected through a DC amplifier (M-4A, W-P Instruments, Inc.) to an oscilloscope and a pen recorder (Gould Brush Recorder, model 280).

Photostimulation. The dual-beam photostimulator, employing $100 \mathrm{~W}$ tungsten halogen lamps, has been previously described (Dowling and Ripps, 1971; Hedden and Dowling, 1978). The size of the light spot on the retinal surface could be varied from 0.1 to $8 \mathrm{~mm}$ (full field). Light intensity was attenuated by calibrated neutral filters over a range of 8 $\log$ units. The unattenuated intensity $(\log I=0)$ of the 2 white light beams was $1.54 \times 10^{2} \mu \mathrm{W} \mathrm{cm} \mathrm{cm}^{-2}$, and the intensities noted in the text are in $\log$ units relative to this intensity. Unless otherwise specified, flashes of white light were used throughout. Monochromatic lights between 420 and $720 \mathrm{~nm}$, provided by narrow-band interference filters, were used for determination of the spectral sensitivity of rod horizontal cells and for classification of cone horizontal cells. The maximum intensity of the monochromatic light was $4.9 \times 10^{11}$ quanta $\mathrm{cm}^{-2} \mathrm{sec}^{-1}$ at $520 \mathrm{~nm}$. Duration of light flashes was controlled by magnetic shutters and set at $500 \mathrm{msec}$ throughout.

Identification of horizontal cells. The different types of horizontal cells were identified by previously established criteria (Werblin and Dowling, 1969; Kaneko, 1970; Mitarai et al., 1974; Yang et al., 1982b; Mangel et al., 1985). All horizontal cells recorded showed sustained, graded responses with large receptive fields. L-type cone horizontal cells were located most distally in the retina, and they hyperpolarized in response to all spectral stimuli with a peak sensitivity at around $600 \mathrm{~nm}$. Responses of C-type horizontal cells differed in polarity depending on the stimulus wavelength, and in the white perch, they were always biphasic; the cells hyperpolarized to short and intermediate regions of the spectrum but depolarized to deep-red $(>680 \mathrm{~nm})$ stimuli. C-type cells in the white perch retina were $0.5 \mathrm{log}$ unit more sensitive to white light compared to L-type cells, and they resided more proximally in the retina. Rod horizontal cells were the most proximally located of all horizontal cells and were impaled after the pipettes had penetrated through L- and C-type cone horizontal cells. The rod cells gave slower responses and were at least $2 \log$ units more sensitive to white light than were L-type cone horizontal cells.

The responses of cone horizontal cells are strongly suppressed after prolonged dark adaptation; thus, their responses were initially too small to classify. The classification of cone horizontal cells into L- or C-type was possible only when the retina had been illuminated by background lights. In all experiments, we tried to present light spots approximately centered over the impaled cells. In prolonged dark-adapted retinas this was accomplished by moving a small light spot $(0.4 \mathrm{~mm}$ diameter $)$ around the receptive field of a rod horizontal cell until a maximum response was obtained. Since the rod horizontal cells were highly sensitive to light, a dim light spot $(\log I=-4.75)$ could be used for this purpose, which avoided disturbing the prolonged dark-adapted state of the cone horizontal cells. In short-term dark-adapted retinas the same procedure was performed using the responses of cone horizontal cells. 


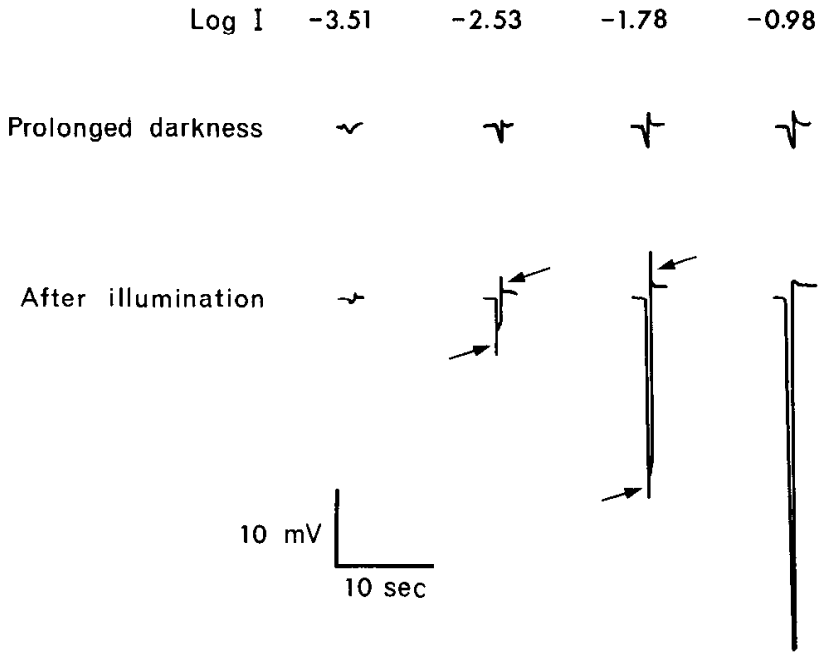

Figure 1. Responses of an L-type cone horizontal cell recorded from a fish dark-adapted for more than $2 \mathrm{hr}$. The upper row shows responses of the cell to full-field flashes of increasing intensity recorded in prolonged darkness. Although the cell showed a normal threshold response to a dim flash $(\log I=-3.51)$, the maximum amplitude to a bright flash ( $\log I=-0.98)$ was only $3 \mathrm{mV}$. The lower row shows responses of the cell to the same intensity flashes recorded about $30 \mathrm{sec}$ after a 3 min presentation of moderate background light $(\log I=-1.78)$. Most of the responses had increased in size, and the response amplitude to the brightest flash was $45 \mathrm{mV}$. Note the changes in response waveforms following illumination; the responses were characterized by fast-rising phases, and conspicuous transients at both light onset and offset can be seen in many of the responses (arrows). Intensities of the light flashes, indicated above the record traces, are in log relative units. Flashes of white light were used throughout unless otherwise specified. Flash duration, $500 \mathrm{msec}$.

\section{Results}

Cone horizontal cells

After prolonged dark adaptation, responses of cone horizontal cells were very small, even when elicited with bright flashes. Responses of an L-type cone horizontal cell, recorded from a retina dark-adapted for more than $2 \mathrm{hr}$, to full field flashes of various intensities are shown in the upper row of Figure 1. The cell showed a normal threshold response (about $1 \mathrm{mV}$ ) to a dim flash (Log $I=-3.51$ ), but its responses increased only slightly in amplitude with increasing intensity. Even with the brightest flash employed $(\log I=-0.98)$, the response amplitude of the cell was only $3 \mathrm{mV}$. Moreover, the response waveforms were relatively slow and the time-to-peak of the responses were around $400 \mathrm{msec}$. These features of cone horizontal cells were observed in 52 cells studied in prolonged dark-adapted retinas. Response amplitudes of these cells to flashes of $\log I=-0.98$ averaged $3.5 \pm 2.1 \mathrm{mV}$.

\section{Effects of background illumination}

Response amplitudes of L-type horizontal cells were dramatically enhanced following background illumination. The lower row of Figure 1 shows responses of the cell, whose responses are illustrated in the top row, to the same intensity flashes about $30 \mathrm{sec}$ after a $3 \mathrm{~min}$ presentation of a moderate background light to the light ( $\log I=-1.78)$. Presentation of the background light resulted in 2 significant changes in the responses of the cell. First, while the response to the $\operatorname{dim}$ flash $(\log I=-3.51)$ still remained small, all other responses increased dramatically in amplitude so that the response to the brightest flash ( $\log I=$ -0.98 ) was $45 \mathrm{mV}$. In addition, characteristic changes in waveform occurred. The rising phase of the responses became much faster and the time-to-peak was shorter than $150 \mathrm{msec}$. Furthermore, an initial transient at flash onset (on-transient) and a depolarizing rebound at flash offset (off-rebound) could be clearly seen in many of the responses (arrows, Fig. 1).

Figure 2 shows changes in membrane potential and response waveform of another representative L-type cone horizontal cell recorded in a prolonged dark-adapted retina during a $10 \mathrm{~min}$ presentation of a dim background light ( $\log I=-2.53)$. The background light initially hyperpolarized the cell by about 2 $\mathrm{mV}$; each minute thereafter, the background light was turned off for a few seconds. When the membrane potential of the cell stabilized, it was recorded (data points in Fig. 2), and a response to a moderate flash ( $\log I-1.78)$ elicited. The initial dark membrane potential of the cell was $-17 \mathrm{mV}$. Following the presentation of the background light, the cell slowly hyperpolarized by $7 \mathrm{mV}$ in the first $5 \mathrm{~min}$; the membrane potential then remained constant. Response amplitudes increased from 3 to

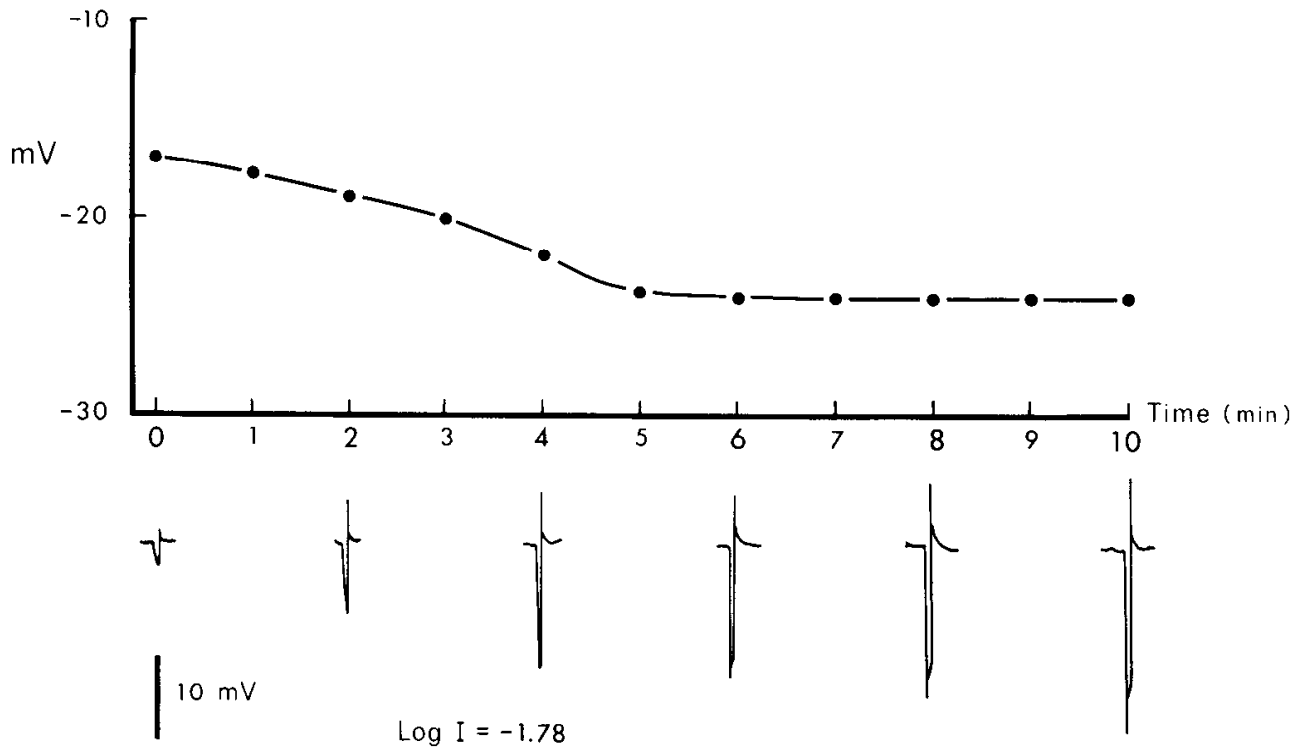

Figure 2. Changes in membrane potential and response waveform of an L-type cone horizontal cell during dim background illumination. Dim background light $(\log I=-2.53)$ was turned on at time 0 . The background light was turned off for about $5 \mathrm{sec}$ each minute thereafter during which time the membrane potential and the response to a moderate test flash $(\log I=-1.78)$ were recorded (see text). The initial membrane potential of the cell was $-17 \mathrm{mV}$; the cell gradually hyperpolarized by 7 $\mathrm{mV}$ in the first $5 \mathrm{~min}$ of background illumination and then leveled off. The light-evoked responses were initially small and slow, but they became larger and faster with time. An initial on-transient developed about $5 \mathrm{~min}$ after onset of the background light; thereafter, it became more and more conspicuous. 


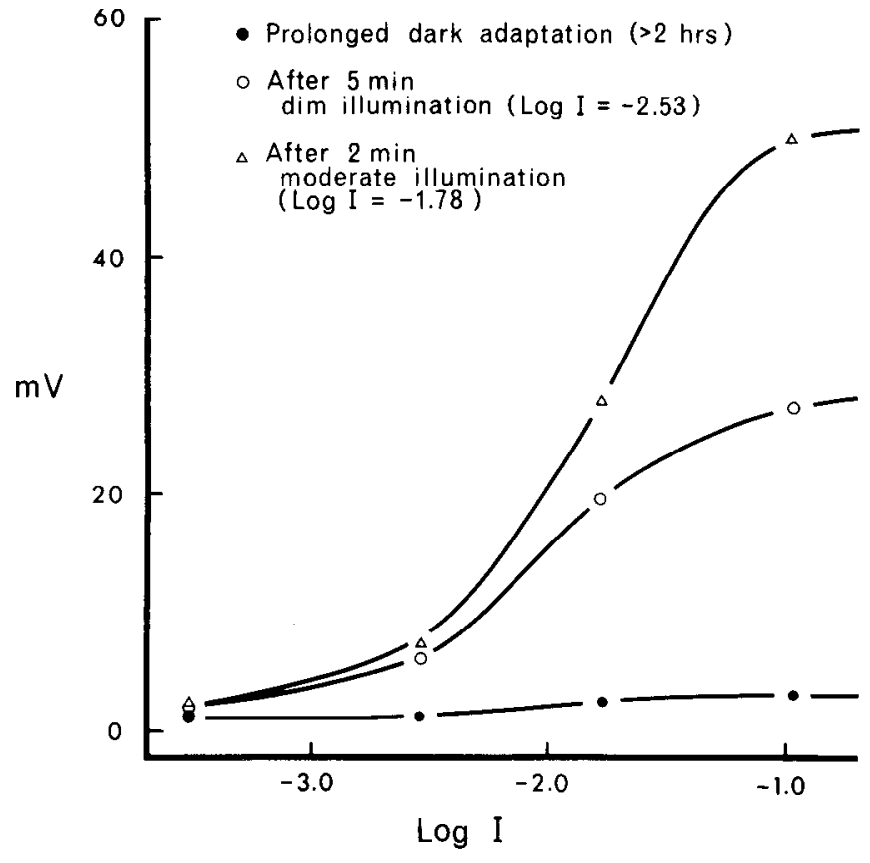

Figure 3. V-Log $I$ curves determined in a single cone horizontal cell before and after presentation of background illumination to the retina. The first $V$-Log I curve, determined in prolonged darkness (filled circles), was extremely flat; response amplitudes increased only by $2.5 \mathrm{mV}$ over a range of $2.55 \mathrm{log}$ units. After the presentation of a dim background light for $5 \mathrm{~min}(\log I=-2.53)$, the $V-\log I$ curve recorded subsequently was considerably steeper (open circles). After an additional 2 min presentation of a moderate background light $(\log I=-1.78)$, the $V$-Log $I$ curve was steeper still and the response amplitude to a bright flash ( $\log I=-0.98$ ) was now $50 \mathrm{mV}$ (triangles).

$16 \mathrm{mV}$ in the first $5 \mathrm{~min}$ and thereafter attained a value of 23 $\mathrm{mV}$ at $10 \mathrm{~min}$. The initial on-transient that developed $5 \mathrm{~min}$ aftcr thc onsct of the background light became more conspicuous with time.

The increase of cone horizontal cell responsiveness depended on the intensity of the background light presented. Figure 3 depicts changes in voltage-intensity $(V-\log I)$ curves following the presentation of background lights of increasing intensity, determined in a single L-type cone horizontal cell. A V-Log $I$ curve for the cell was first recorded in darkness (filled circles). The curve was extremely flat, and the response amplitudes increased by only $2.5 \mathrm{mV}$ over a range of $2.55 \log$ units. Dim full field background light ( $\log I=-2.53)$ was presented to the retina for $5 \mathrm{~min}$. The $V-\log I$ curve recorded subsequently was considerably steeper (open circles), and the response amplitude to a flash of $\log I=-0.98$ had increased from 3 to $25 \mathrm{mV}$. The intensity of the background light was then increased to Log $I=-1.78$, and following a 2 min presentation of this background light, a still steeper $V$-Log $I$ curve was recorded. The response amplitude to the bright flash $(\log I=-0.98)$ was now $50 \mathrm{mV}$. Note that the $V-\log I$ curves of the cell were in the same position on the intensity axis, although they differed dramatically in amplitude. That is, the intensity necessary to evoke a half-maximal response was about the same for all 3 curves. A further increase in intensity of the background light (to Log $I=-0.98)$ did not increase response amplitudes further but did cause the $V$-Log $I$ curve to shift slightly to the right along the intensity axis. This likely reflected a decrease in photoreceptor sensitivity induced by the relatively bright background light.

Similar enhancement in response amplitudes of cone horizontal cells was observed after presenting short $(0.5 \mathrm{sec})$ bright flashes repetitively to a prolonged dark-adapted retina. Figure 4 shows changes in membrane potential and response amplitudes of an L-type cone horizontal cell when flashes of $\log I=$ -0.98 were presented at intervals of $9 \mathrm{sec}$. Following the onset of the flashes, the membrane potential gradually hyperpolarized by $8 \mathrm{mV}$ in the first $7 \mathrm{~min}$ and then stabilized at $-25 \mathrm{mV}$. Changes in response amplitude to the flashes were even more impressive. Initially, the response amplitude to a flash of $\mathrm{Log}$ $I=-0.98$ was only $4 \mathrm{mV}$, but $20 \mathrm{~min}$ after repetitive flash presentations responses of more than $50 \mathrm{mV}$ were recorded. This was also accompanied by noticeable changes in response waveform. The responses recorded in prolonged darkness were
Figure 4. Changes in membrane potential and response amplitudes of a cone horizontal cell following the presentation of bright, full-field flashes $(\log I=-0.98)$ at intervals of 9 sec. The cell recorded was from a prolonged dark-adapted retina and initially had a membrane potential of $-17 \mathrm{mV}$. The responses to the bright flashes dramatically increased in size over time, and the cell gradually hyperpolarized. Initially, the response was only $4 \mathrm{mV}$, but it gradually increased to about $50 \mathrm{mV}$.

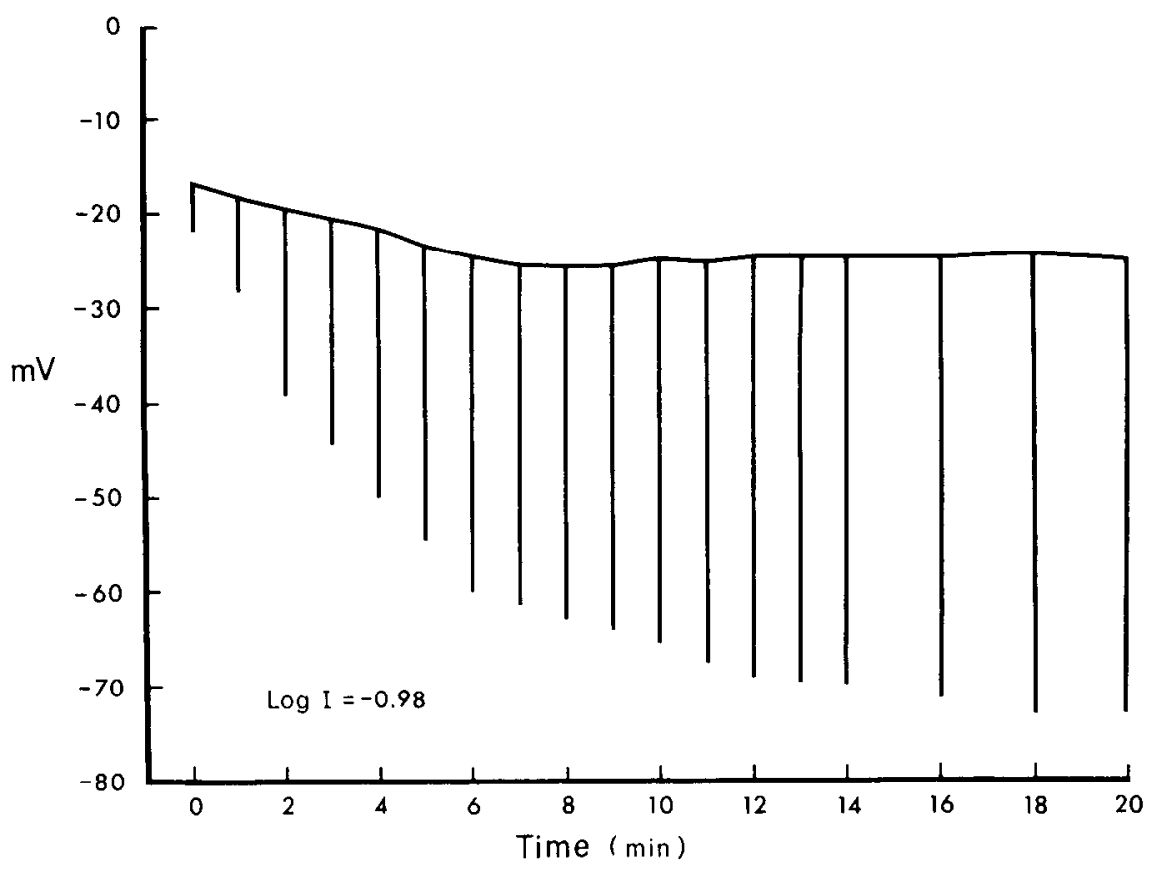




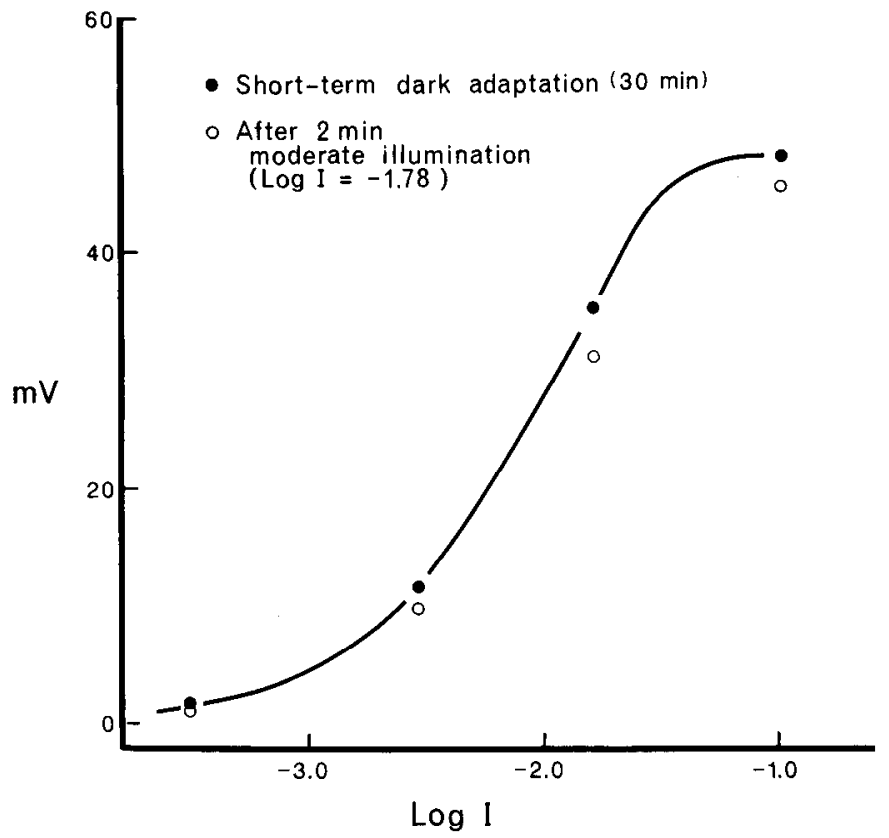

Figure 5. Lack of effects of background light $(\log I=-1.78)$ on the responsiveness of a cone horizontal cell recorded in a retina kept in darkness for only about $30 \mathrm{~min}$ (short-term dark adaptation). The $V_{-}$ Log $I$ curves recorded before and after background illumination were very similar.

relatively slow, but they gradually became faster following the repetitive flash presentations and were characterized by conspicuous on-transients (not shown). The changes in both membrane potential and response amplitudes, observed during the presentation of repetitive flashes were very similar to those induced by steady background illumination.

We have also examined the effects of background lights on cone horizontal cell responsiveness in retinas from fish $(n=3)$ that were kept in complete darkness for $20 \mathrm{~min}$, rather than 2 hr. In these short-term dark-adapted retinas, cone horizontal cells initially exhibited high light responsiveness. Also, their responses were fast and showed conspicuous on-transients. These features are similar to those of cells recorded when prolonged dark-adapted retinas had been exposed to background light. Figure 5 shows $V$-Log $I$ curves of an L-type cone horizontal cell determined in the dark and after background illumination in a short-term dark-adapted retina. The cell was impaled when the retina had been kept in the dark or dim red light for about $30 \mathrm{~min}$. The $V$-Log $I$ curve of the cell when first determined (filled circles) was steep, similar to that for cells recorded in retinas exposed to moderate background light (compare with Fig. 3). Following a 2 min presentation of a moderate background light $(\log I=-1.78)$, the responses of the cell to the same intensity flashes (open circles) were unchanged or were slightly decreased in amplitude. In other words, no background sensitization was observed in such preparations.

\section{Effects of prolonged darkness}

When an isolated retina from a short-term dark-adapted fish was maintained in complete darkness, the responsiveness of the horizontal cells gradually decreased with time (Fig. 6). In these experiments, the fish were kept in complete darkness for $20 \mathrm{~min}$ before cyc cnuclcation and retinal disscetion. An additional 10 min elapsed before a cone horizontal cell was penetrated with the micropipette, so that the total time for the cell in the dark or dim red light before the recording was made was approximately $30 \mathrm{~min}$. The retina was then maintained in the dark and the response properties of the cells (responsiveness, membrane potential, and waveform) monitored. Figure $6 a$ shows examples of $V$-Log $I$ curves measured at different times from a typical cell. The first $V$-Log $I$ curve determined at 30 min was rather steep and typical of those of short-term dark-adapted retinas, i.e., the response amplitude to a flash of $\log I=-0.98$ was 52 $\mathrm{mV}$. However, with further time in the dark, the responses of the recorded cell slowly decreased in amplitude, and the $V$-Log $I$ curves subsequently became less steep. After $45 \mathrm{~min}$ in the a

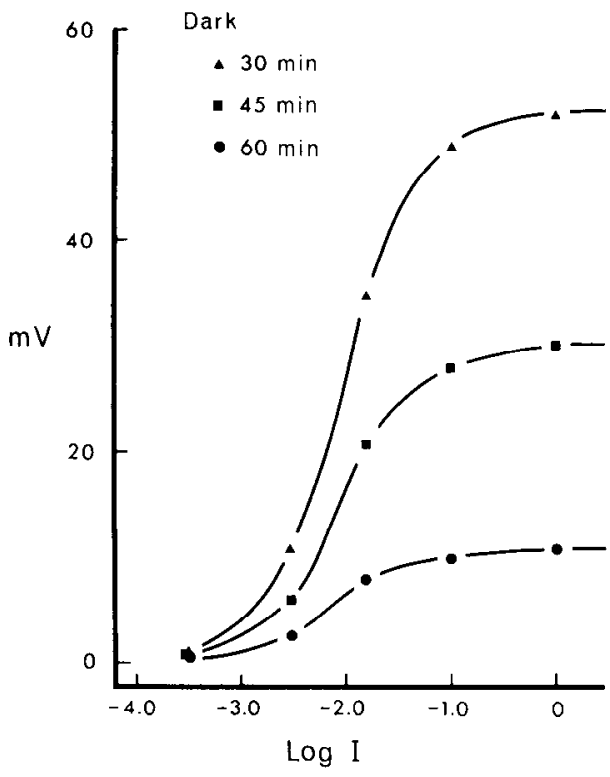

b

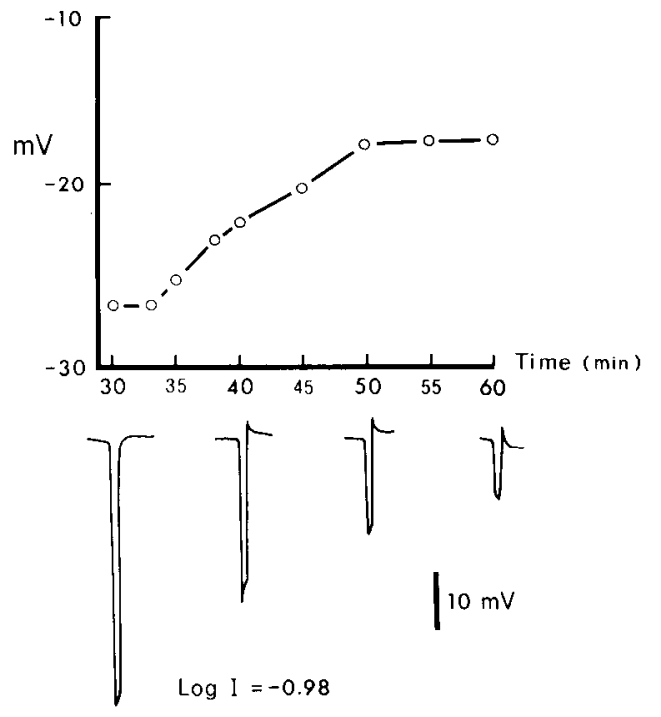

Figure 6. Effects of prolonged darkness on the response properties of a cone horizontal cell. $a$, First $V$ - $\log I$ curve (triangles) was recorded after the retina had been in darkness for $30 \mathrm{~min}$. Subsequent $V$-Log $I$ curves, determined at $45 \mathrm{~min}$ (squares) and $60 \mathrm{~min}$ (circles) in the dark, were much less steep. $b$, Change in the membrane potential of the cell as a function of time in the dark is shown in the upper part, while responses to a bright flash $(\log I=-0.98)$ recorded at different times in the dark are shown in the lower part of the figure. Note that the cell gradually depolarized, and the response became smaller and slower with time in the dark. 


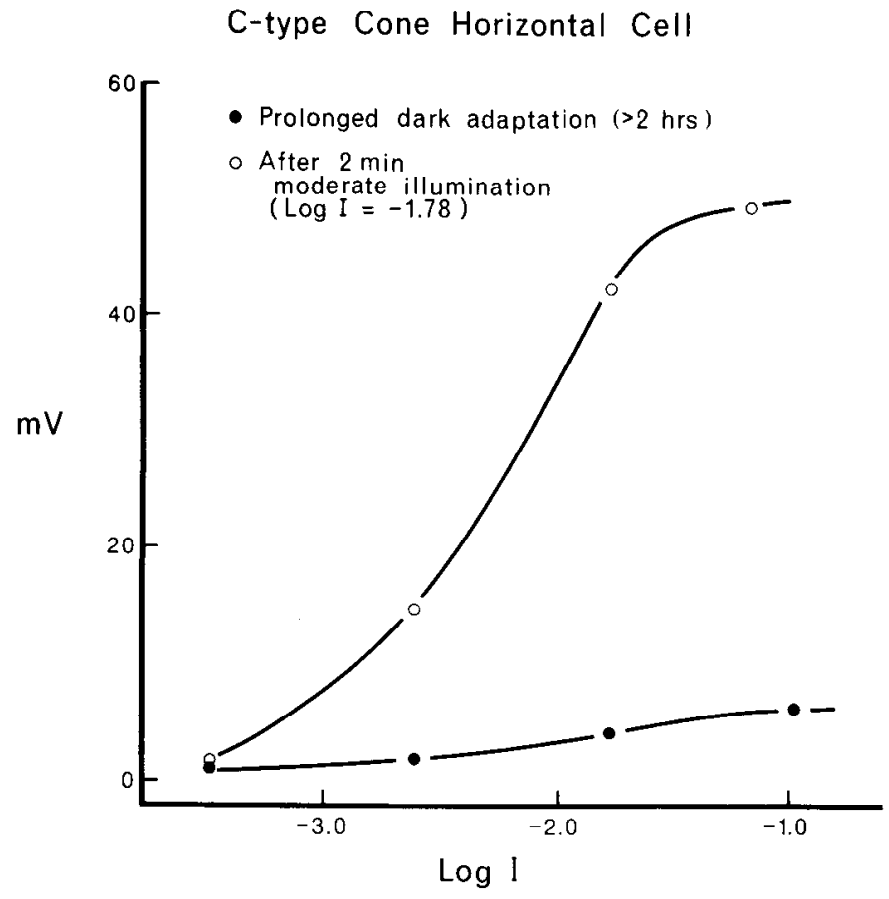

Figure 7. Effects of background illumination on the light responsiveness of a C-type cone horizontal cell recorded from a fish dark-adapted for more than $2 \mathrm{hr}$. The $V-\log I$ curve first determined in prolonged darkness (filled circles) was very flat. Following a 2 min presentation of moderate background light ( $\log I=-1.78)$, the $V$-Log $I$ curve subsequently determined (open circles) was considerably steeper and the response amplitude to a bright flash $(\log I=-0.98)$ increased from about 6 to $49 \mathrm{mV}$.

dark, the maximum response amplitude had decreased to about $28 \mathrm{mV}$, and by $60 \mathrm{~min}$ the response amplitude to a flash of Log $I=-0.98$ was only $10.5 \mathrm{mV}$. The cell was lost shortly thereafter, and further changes in the $V$-Log $I$ curve could not be traced. Similar results were obtained in 3 other short-term dark-adapted retinas maintained in darkness.

Figure $6 b$ shows changes in the membrane potential and response waveform of this cell as a function of time in the dark. The initial membrane potential of the cell in the short-term dark-adapted retina was morc negative $(-26 \mathrm{mV}$ in this cell, $-25 \pm 4.4 \mathrm{mV}$ on average, $n=6$ ) than that of cells recorded in prolonged dark-adapted retinas $(-18 \pm 3.8 \mathrm{mV}$ on average, $n=28 ; p<0.01, t$ test). With additional time in the dark, the cell gradually depolarized and attained a resting level of -17.5 $\mathrm{mV}$ at $50 \mathrm{~min}$. Changes in the response waveform were also observed. Initially the response to a bright test flash $(\log I=$ -0.98) had a fast rising phase and an on-transient, and this waveform persisted for approximately $40 \mathrm{~min}$ in the dark. The response then became slower, and the on-transient gradually diminished until it became indiscernible at $60 \mathrm{~min}$.

In other experiments, retinas were dissected from fish maintained in the dark for more than $2 \mathrm{hr}$ and then exposed to dim (Log $I=-2.53$ ) background light. As expected, the light responsiveness of cone horizontal cells was enhanced by the background light. When these retinas were subsequently returned to complete darkness, light responsivencss decreased slowly with time in a fashion similar to that shown in Figure 6. However, it was found that following the presentation of a brighter background light ( $\log I=-1.78)$ to prolonged dark-adapted retinas, cone horizontal cells remained at a stable, highly responsive
Rod Horizontal Cell

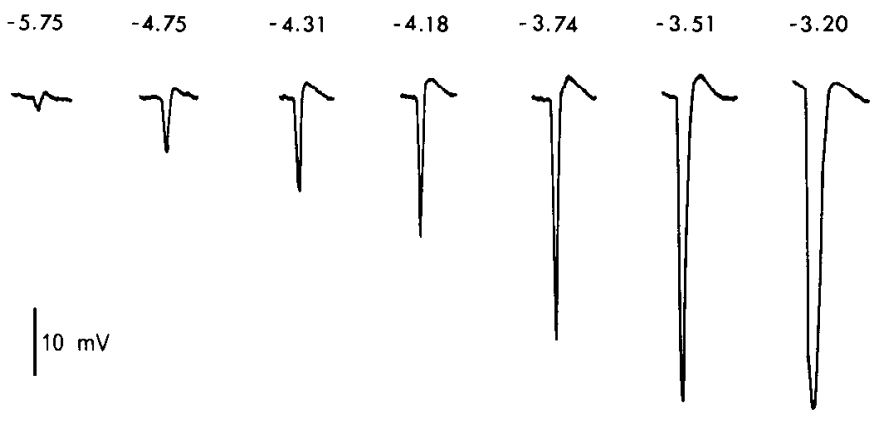

Figure 8. Responses of a rod horizontal cell recorded from a prolonged dark-adapted retina to full-field flashes of increasing intensity. The flash intensities are indicated above the traces. The responses were relatively slow and without on-transients.

state for long periods and they did not return to the low responsive state even when retinas were left in darkness for more than $2 \mathrm{hr}$.

\section{C-type cone horizontal cells}

Although most of our recordings were from L-type cone horizontal cells, we also observed the background sensitization phenomenon in C-type cone horizontal cells. Figure 7 shows $V$ I.og $I$ curves recorded from a representative C-type cell ( 1 of 8 cells studied) prior to and following a 2 min presentation of moderate background light $(\log I=-1.78)$ to a prolonged darkadapted retina. As was the case with L-type cone horizontal cells, the $V$-Log $I$ curve recorded following the background light was much steeper than that recorded in prolonged darkness. Changes in membrane potential and response waveform occurring in C-type cells after the presentation of background illumination were also comparable to those observed in L-type cells.

\section{Responses of rod horizontal cells and effects of background illumination}

Although cone horizontal cells exhibited very small responses in retinas maintained in prolonged darkness, rod horizontal cells typically showed large responses in both short- and long-term dark-adapted retinas. Compared with cone horizontal cells, rod horizontal cells characteristically had larger resting potentials (about $-35 \mathrm{mV}$ ) and were more sensitive to light. A threshold response $(\sim 2 \mathrm{mV})$ could be elicited from rod horizontal cells by a light flash as $\operatorname{dim}$ as $\log I=-5.75$. We did notice that the rod horizontal cells in short-term dark-adapted retinas tended to have somewhat smaller maximum amplitudes $(\sim 25 \%)$ than was the case in prolonged dark-adapted preparations.

Figure 8 shows responses of a rod horizontal cell in prolonged darkness to light flashes of increasing intensity. The responses were relatively slow and lacked initial on-transients. It is noteworthy that a flash of $\log I=-3.51$, although just eliciting a threshold response from cone horizontal cells (Fig. 1), saturated the response of this cell. Further increases in intensity led to a slower recovery of the membrane potential of the cell to the dark resting level.

In Figure 9 the $V$ - $\log I$ curve of a rod horizontal cell in prolonged darkness is compared with the $V$ - $\log I$ curves of a representative L-type cone horizontal cell determined in pro- 


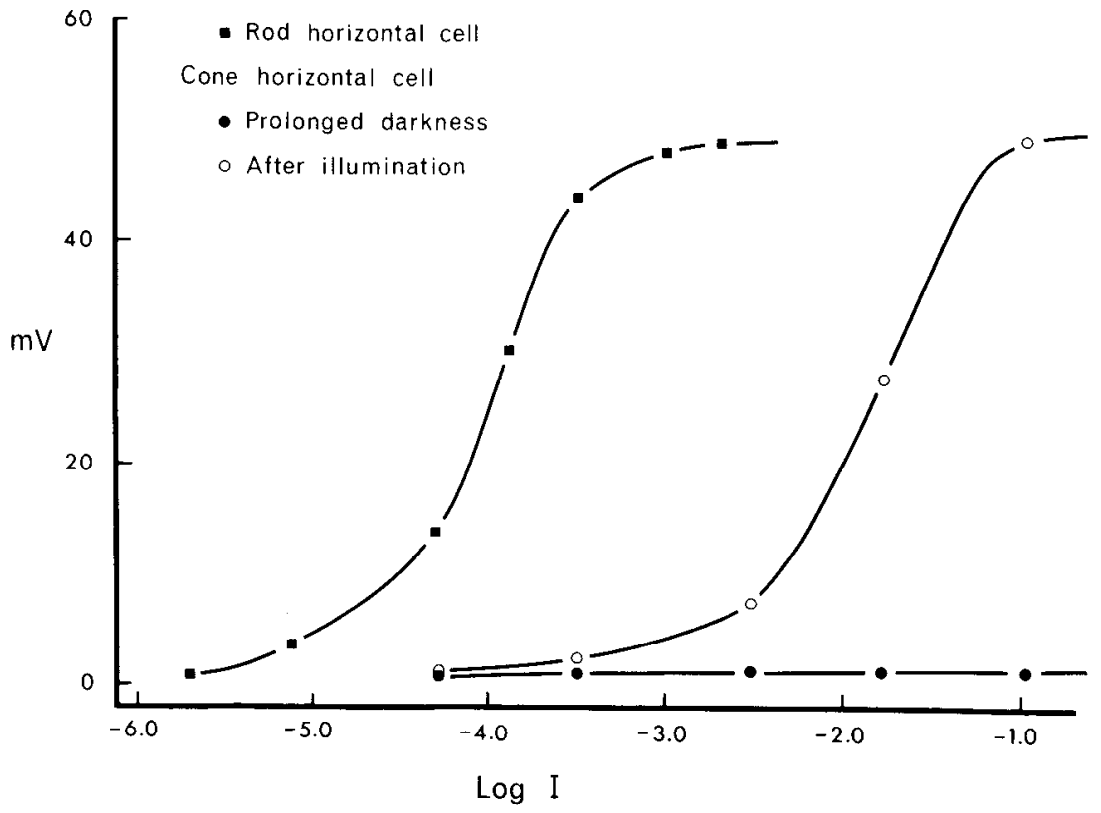

Figure 9. V-Log I curves of a rod horizontal cell and of an L-type cone horizontal cell recorded in a single retina. The $V$ - $\log I$ curve of the rod horizontal cell (squares) was determined in prolonged $(>2 \mathrm{hr})$ darkness, while the curves of the cone horizontal cell were determined first in prolonged darkness (filled circles) and after a 3 min presentation of moderate background light $(\log I=-1.78$, open circles). The $V-$ Log $I$ curve of the rod horizontal cell is shifted to the left by $2 \log$ units on the intensity axis. longed darkness and following background illumination. (Flashes of white light were used in these experiments.) In prolonged darkness the $V$-Log $I$ functions of the rod and cone horizontal cells were strikingly different. Following a $3 \mathrm{~min}$ presentation of moderate background light $(\log I=-1.78)$ to the retina, which enhanced the light responsiveness of the cone cell to its maximum level, the $V$-Log $I$ curves of the rod and conc cclls were now similar in shape, although the $V$-log $I$ curve for the rod horizontal cell was located about $2 \log$ units to the left on the intensity axis. We found that the intensity of light needed to begin to sensitize cone horizontal cells was about $\log I=$ -3.00 (see Fig. 3). This intensity of illumination produces responses in rod horizontal cells that are near or at saturation levels.

When a background light of $\log I=-2.53$ was presented to the retina for $5 \mathrm{~min}$, rod horizontal cells were maximally hyperpolarized (by -40 to $-50 \mathrm{mV}$ ), and they remained at this saturation level for as long as the background light remained on. When the background light was turned off, the membrane potential of the cell returned to the resting level slowly, and it took about $1 \mathrm{~min}$ for full membrane potential recovery. When a $V$-Log $I$ curve subsequently recorded was compared with one determined before the background illumination, it was invariably found, as shown in Figure 10, that the former curve was slightly displaced to the right on the intensity axis by $0.2-0.3$ $\log$ unit. No enhancement of light responsiveness was ever observed in rod horizontal cells following background illumination.

\section{Modulation of horizontal cell responsiveness in carp retinas}

Modulation by prolonged darkness and background illumination of cone horizontal cells of the carp retina was also examined. In isolated and perfused carp retinas, the extent of modulation of the cone horizontal cells was considerably less than that observed in the white perch retina. In prolonged dark-adapted relinas, maximum response amplitudes were typically between 20 and $30 \mathrm{mV}$. After exposure to background lights, the re- sponses increased in size to between 40 and $50 \mathrm{mV}$, and the cells' resting membrane potential hyperpolarized. Changes in response waveform, similar to those observed in the white perch retina, occurred as well. That is, responses usually became faster and showed more conspicuous on-transients. Figure 11 illustrates typical changes in $V$-Log $I$ curves of an L-type cone horizontal ccll following background illumination. The $V$ - $\log I$

Rod Horizontal Cell

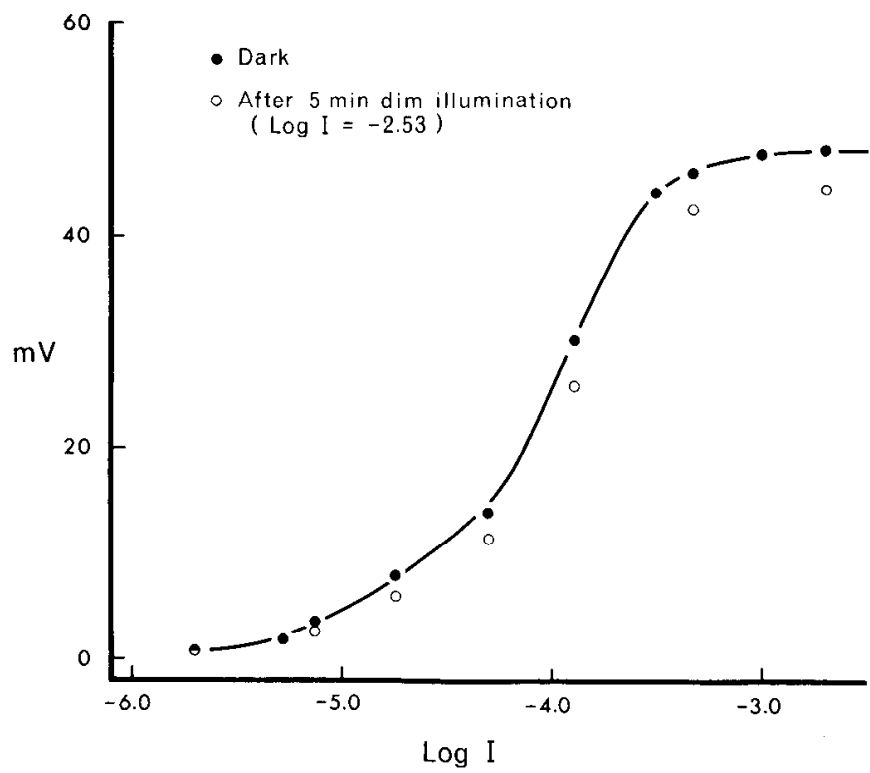

Figure 10. Lack of effects of dim background light $(\log I=-2.53)$ on the responsiveness of a rod horizontal cell. A $V$ - $\log l$ curve was first determined in prolonged ( $>2 \mathrm{hr}$ ) darkness (filled circles). Dim background light $(\log I=-2.53)$, which maximally hyperpolarized the cell by $50 \mathrm{mV}$, was then presented for $5 \mathrm{~min}$. After the background light was turned off, and the membrane potential had returned to the original dark level, a second $V$-Log $I$ curve was determined (open circles). The $2 V$-Log $I$ curves were quite similar. 


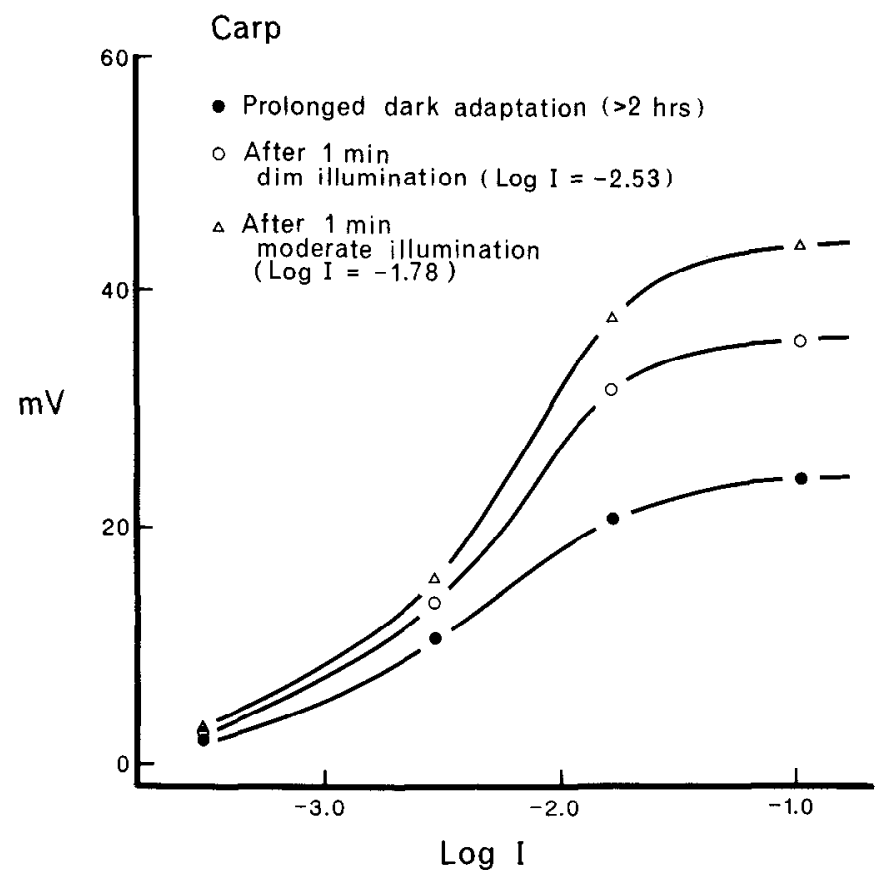

Figure 11. Enhancement of the light responsiveness of an L-type cone horizontal cell by background illumination in the carp retina. The first $V$-Log $I$ curve was determined in prolonged $(>2 \mathrm{hr})$ darkness (filled circles). The second curve, determined after a 1 min presentation of $\operatorname{dim}$ background light ( $\log I=-2.53)$, was steeper (open circles). Subsequent presentation of a moderate background light $(\log I=-1.78)$ for $1 \mathrm{~min}$ resulted in a still steeper curve (triangles). Though less dramatic, the background sensitization phenomenon in the carp was qualitatively similar to that observed in the white perch retina.

curve for the cell determined in darkness was relatively shallow, and the response amplitude to a flash of $\log I=-0.98$ was 24 $\mathrm{mV}$. After dim background light ( $\log I=-2.53)$ had been presented to the retina for $1 \mathrm{~min}$, the $V$-Log $I$ curve recorded subsequently was considerably steeper, and the response amplitude to a flash of $\log I=-0.98$ was to $35.5 \mathrm{mV}$. Re-exposure of the retina to background light of the same intensity failed to change response amplitudes, but a $0.75 \mathrm{log}$ unit increase in intensity of the background light (to $\log I=-1.78$ ) resulted in a still steeper $V$-Log $I$ curve, and the response amplitude to the flash of $\log I=-0.98$ increased to $44 \mathrm{mV}$. Following presentation of the background lights, the cell's resting potential also gradually hyperpolarized by $7 \mathrm{mV}$. As in the white perch retina, the background sensitization phenomenon was not observed in short-term dark-adapted retinas.

\section{Discussion}

Cone horizontal cells in the white perch show only small responses (maximum of about $4 \mathrm{mV}$ ) after the retina has been in the dark for a prolonged period ( $>2 \mathrm{hr}$ ), indicating that the light responsiveness of these cells is strongly suppressed following prolonged darkness. The light responsiveness increases dramatically following the presentation of background lights to the retina. The extent of the light sensitization depends on the intensity of the background illumination. Brighter background lights cause larger increases in responsiveness (up to maximum) unless they produce some light adaptation of the photoreceptors. Furthermore, relatively bright flashes presented repetitively produce the same effects as do continuous background lights, sug- gesting that this sensitization phenomenon is independent to a certain extent of the temporal pattern of light presentation.

These results indicate that cone horizontal cells require background illumination to maintain high light responsiveness. Earlier studies reported findings in accord with this conclusion. When dark adaptation of L-type cone horizontal cells was studied in goldfish eyecups in fish with the circulation intact (Yang et al., 1982a), it was found that the responses of the cells increased in amplitude for approximately $20 \mathrm{~min}$ after the beginning of dark adaptation but then significantly decreased in amplitude after the preparation was left in the dark for more than $1 \mathrm{hr}$. Further, it was shown that dim background illumination restored the light responsiveness of cone horizontal cells following prolonged darkness to maximum levels, i.e., to levels observed after $30 \mathrm{~min}$ of darkness. With isolated superfused carp retinas, Mangel and Dowling $(1985,1987)$ observed that, following prolonged darkness, response amplitudes of cone horizontal cells to large spots of light $(>1.6 \mathrm{~mm}$ diameter) were significantly smaller than were responses elicited with the same stimuli from cone horizontal cells of short-term dark-adapted retinas.

Our results are consistent with, and extend, these previous findings. For example, resting membrane potentials and response waveforms of horizontal cells were carefully monitored in short-and long-term dark-adapted retinas and during the shifts between these states. In prolonged dark-adapted retinas the resting membrane potential of cone horizontal cells was at a less hyperpolarized level $(\sim-18 \mathrm{mV})$ than was the resting membrane potential of cells in short-term dark-adapted retinas $(\sim-25$ $\mathrm{mV}$ ). During the presentation of background lights to prolonged dark-adapted retinas, the horizontal cells hyperpolarized in the first $5 \mathrm{~min}$ by $5-7 \mathrm{mV}$ and thereafter remained at the more hyperpolarized level. Conversely, when short-term dark-adapted retinas were kept in the dark for long periods, the cells gradually depolarized with time, by $5-7 \mathrm{mV}$, and remained at the less hyperpolarized level $(\sim-18 \mathrm{mV})$. Curiously, the light responsiveness of cone horizontal cells appeared to change more gradually than the membrane potential; that is, the light responsiveness of the cells continued to change even after the resting membrane potentials had reached stable levels. However, it is clear that mechanisms regulating both membrane potential and light responsiveness of cone horizontal cells come into play when the background illumination is altered.

In addition, after prolonged darkness, cone horizontal cells in white perch exhibited relatively slow response waveforms and showed no on-transients. Following background illumination, or in short-term dark-adapted retinas, the responses of the cone horizontal cells were faster and were characterized by conspicuous on-transients. On-transients of cone horizontal cell responses have generally been attributed to feedback interactions between the horizontal cells and the photoreceptors (Baylor et al., 1971; O’Bryan, 1973; Fuortes et al., 1973; Burkhardt, 1977; Wu and Dowling, 1980). In prolonged darkness, cone horizontal responses are so depressed in amplitude that the strength of feedback on to the receptors must be minimal, perhaps accounting for the lack of on-transients in horizontal cells in prolonged dark-adapted retinas.

A possible explanation that might be advanced for the decreased responsiveness of cone horizontal cells in isolated retinas after prolonged darkness is damage to cones caused by the separation of the retina from the pigment epithelium. Cones elongate in the dark (Burnside and Nagle, 1983; Burnside and 
Dearry, 1986), and some of the cones could be torn off during the isolation of the retina from the eyecup after prolonged darkness. However, that background illumination enhances the light responsiveness of cone horizontal cells to levels comparable to those observed in short-term dark-adapted retinas eliminates the possibility that cone damage is responsible for the decreased responsiveness in prolonged darkness.

\section{Rod horizontal cells}

Rod horizontal cells were readily recorded in the white perch retina. These cells were located most proximally of all horizontal cells; they were at least $2 \log$ units more sensitive than cone horizontal cells, and their spectral sensitivity peaked at about $520 \mathrm{~nm}$. Rod horizontal cells yielded large responses when recorded from prolonged dark-adapted retinas. Furthermore, presentation of dim background illumination ( $\log I=-2.53)$ slightly decreased, rather than enhanced, the responsiveness of the rod horizontal cells in the prolonged dark-adapted state. When background light was increased to $\log I=-1.78$, it was found that the light responsiveness of rod horizontal cells was strongly depressed and that the membrane potential remained at a maximally hyperpolarized level for long periods of time, even after the background light had been turned off. Recovery of both light responsiveness and membrane potential following the moderate background light adaptation was impossible to monitor to completion but appeared to require at least $30 \mathrm{~min}$. We conclude that rod horizontal cells are maximally responsive in the dark and that their responsiveness changes only as rod responsiveness changes. In other words, the background sensitization phenomenon is observed only in cone horizontal cells.

An obvious question is whether rod-cone interaction is involved in the suppression of cone horizontal cell responses in prolonged darkness. It is possible that cone responses or cone pathways could be suppressed by rod activity, and rod-cone interaction has been reportcd in amphibians (Hood, 1972; Frumkes, 1987), mammals (Rodieck and Rushton, 1976), and man (Goldberg et al., 1983, Coletta and Adams, 1984, Frumkes et al., 1985). Although this is a plausible speculation, our evidence argues against it. First, presentation to the prolonged darkadapted retina of a background light ( $\log I=-4.75)$ that was below threshold for the cone horizontal cells but strongly activated the rod horizontal cells (see Fig. 9) failed to enhance the light responsiveness of cone horizontal cells. Furthermore, the responsiveness of cone horizontal cells exposed to dim background light ( $\log I=-2.53)$ could be further enhanced by a brighter background light $(\log I=-1.78)$. Both of these backgrounds were of sufficient intensity to induce maximal responses in the rods (Fig. 9), and therefore they should have exerted equivalent effects on the cone horizontal cells if the light sensitization were related to rod responses. That the increase of responsiveness requires background lights bright enough to stimulate the cone horizontal cells and that the sensitizing effect is roughly graded over the intensity range of the cone horizontal cells suggest that the sensitization phenomenon is cone mediated.

\section{Horizontal cells in carp and other species}

In the carp retina, a similar suppression of light responsiveness of cone horizontal cells in prolonged darkness and an enhancement of light responsiveness by background illumination have also been observed in accord with earlier results (Mangel and
Dowling, 1985, 1987). However, although the same dissection and recording procedures were followed, carp cone horizontal cells from prolonged dark-adapted preparations showed responses clearly larger than those recorded from cone horizontal cells in the white perch retina under similar conditions. While the response amplitudes of cone horizontal cells to a bright flash $(\log I=-0.98)$ were only about $4 \mathrm{mV}$ in the perch, they were about $24 \mathrm{mV}$ in the carp. This may reflect a species difference in the extent of suppression of cone horizontal cells by prolonged darkness. On the other hand, whereas in the perch retina cone horizontal cells were still under strong suppression following dissection and preparation set-up, the dim red light used for dissecting and set-up might have sensitized cone horizontal cells to some extent in the carp retina. This explanation is supported by observations that the response amplitudes of cone horizontal cells recorded in the intact goldfish decreased to levels comparable to those of the white perch cells when the preparation was kept in complete darkness for more than $1 \mathrm{hr}$ (Yang et al., 1982a). Isolation of the retina from the eye could also affect the extent of dark suppression of cone horizontal cells, and this might vary among species. It has recently been shown that centrifugal fibers make synapses on interplexiform cells in teleosts (Zucker and Dowling, 1987), and, as shall be shown in the accompanying papers (Tornqvist et al., 1988; Yang et al., 1988), the interplexiform cells appear to play a major role in regulation of these phenomena. Alteration of synaptic input to the interplexiform cells, by isolating the retina from central influences, could affect the release of neuroactive substances from the interplexiform cells.

Suppression of the light responsiveness of cone-driven horizontal cells in prolonged darkness may be a more general phenomenon, and not limited to these cells in the teleost retina. Horizontal cells are known to mediate the antagonistic surround responses of photoreceptors, bipolar cells, and many ganglion cells (Werblin and Dowling, 1969; Naka, 1972; Naka and Witkovsky, 1972; Miller and Dacheux, 1976, Mangel and Miller, 1987), and it has long been recognized that the antagonistic surround responses of ganglion cells are reduced in strength or are entirely absent following a prolonged period in the dark. This has been reported for the cat (Barlow et al., 1957; EnrothCugell and Lennie, 1975), frog (Donner and Reuter, 1965), and rabbit (Masland and Ames, 1976). In the cat and frog, it was shown that this phenomenon is not related to the switch from cone to rod vision but to some other mechanism (Barlow et al., 1957; Donner and Reuter, 1965). Suppression of the responsiveness of cone horizontal cells after prolonged darkness could account for this change in antagonistic surrounds of ganglion cell receptive fields (see Mangel and Dowling, 1987).

Finally, it is noteworthy that the double color-opponent ganglion cells in the goldfish retina were reported to lose color opponency within $1 \mathrm{hr}$ of dark-adaptation and then to become entirely unresponsive during the next $2 \mathrm{hr}$ (Raynauld et al., 1979). The loss of color opponency of ganglion cells could be accounted for by suppression of cone horizontal cells after prolonged darkness, but it is difficult to explain the entire failure of ganglion cells to respond to light stimulation on this basis. That is, horizontal cells are thought to provide ganglion cells with the surrounds of their receptive fields but not their center field responses (Werblin and Dowling, 1969; Naka, 1972; Naka and Witkovsky, 1972). Loss of the light responsiveness in receptive field centers of ganglion cells suggests that cone signals may be suppressed more generally in the retina after prolonged 
darkness, perhaps in bipolar cells or in the cones themselves, but this remains to be shown.

\section{References}

Barlow, H. B., R. Fitzhugh, and S. W. Kuffler (1957) Change of organization in the receptive fields of the cat's retina during dark adaptation. J. Physiol. (Lond.) 137: 338-354.

Baylor, D. A., M. F. G. Fuortes, and P. M. O'Bryan (1971) Receptive fields of cones in the retina of the turtle. J. Physiol. (Lond.) 214: 265294.

Burkhardt, D. A. (1977) Responses and receptive field properties of cones in perch retina. J. Neurophysiol. 40: 53-62.

Burnside, B., and A. Dearry (1986) Cell motility in the retina. In The Retina: A Model for Cell Biology Studies, Part I, R. Adler and D. Farber, eds., pp. 151-206, Academic, Orlando, FL.

Burnside, B., and B. Nagle (1983) Retinomotor movements of photoreceptors and retinal pigment epithelium: Mechanisms and regulation. In Prog. Retinal Res., Vol. 2, N. N. Osborne and G. J. Chader, eds., pp. 67-110, Pergamon, New York.

Chino, $Y_{\text {. }}$ and $Y$. Hashimoto (1985) Identification of dopaminergic cells in the inner retina of Japanese dace. Invest. Ophthalmol. Vis. Sci. Suppl. 26: 116.

Coletta, N. J., and A. J. Adams (1984) Rod-cone interaction in flicker detection. Vison Res. 24: 1333-1340.

Donner, K. O., and T. Reuter (1965) The dark-adaptation of single units in the frog's retina and its relation to the regeneration of rhodopsin. Vision Res. 5: 615-632.

Dowling, J. E., and B. Ehinger (1975) Synaptic organization of the amine-containing interplexiform cells of the goldfish and Cebus monkey retinas. Science 188: 270-273.

Dowling, J. E, and B. Ehinger (1978) The interplexiform cell system. I. Synapses of the dopaminergic neurons of the goldfish retina. Proc. R. Soc. London [Biol.] 201: 7-26.

Dowling, J. E., and H. Ripps (1971) S-potentials in the skate retina: Intracellular recordings during light and dark adaptation. J. Gen. Physiol. 58: 163-189.

Ehinger, B., B. Falck, and A. M. Laties (1969) Adrenergic neurons in teleost retina. Z. Zellforsch. 97: 285-297.

Enroth-Cugell, C., and P. Lennie (1975) The control of retinal ganglion cell discharge by receptive field surrounds. J. Physiol. (Lond.) 247: 551-578.

Frumkes, T. E. (1987) Tonic inhibition of cone pathways by rods in distal vertebrate retina. Invest. Ophthalmol. Vis. Sci. Suppl. 28: 50.

Frumkes, T. E., T. Eysteinsson, and G. B. Arden (1985) Tonic inhibition of rod-cone pathways by dark-adapted rods. Invest. Ophthalmol. Vis. Sci. Suppl. 26: 114.

Fuortes, M. G. F., E. A. Schwartz, and E. J. Simon (1973) Colour dependence of cone responses in the turtle retina. J. Physiol. (Lond.) 234: 199-216.

Goldberg, S. H., T. E. Frumkes, and R. W. Nygaard (1983) Inhibitory influence of unstimulated rods in the human retina: Evidence provided by examining cone flicker. Science 221 : 180-182.

Hankins, M. W., and K. H. Ruddock (1984) Hyperpolarization of fish retinal horizontal cells by kainate and quisqualate. Nature $308: 360$ 362.

Hedden, W. L., and J. E. Dowling (1978) The interplexiform cell system. II. Effects of dopamine on goldfish retinal neurones. Proc. R. Soc. London [Biol.] 201: 27-55.

Hood, D. (1972) Suppression of the frog's cone system in the dark. Vision Res. 12: 889-908.

Kaneko, A. (1970) Physiological and morphological identification of horizontal, bipolar and amacrine cells in the goldfish retina. J. Physiol. (Lond.) 207: 623-633.

Lasater, E. M., and J. E. Dowling (1985) Dopamine decreases conductance of the electrical junctions between cultured retinal horizontal cells. Proc. Natl. Acad. Sci. USA 82: 3025-3029.
Mangel, S. C., and J. E. Dowling (1985) Responsiveness and receptive field size of carp horizontal cells are reduced by prolonged darkness and dopamine. Science 229: 1107-1 109.

Mangel, S. C., and J. E. Dowling (1987) The interplexiform-horizontal cell system of the fish retina: Effects of dopamine, light stimulation and time in the dark. Proc. R. Soc. London [Biol.] 231: 91-121.

Mangel, S. C., and R. F. Miller (1987) Horizontal cells contribute to the receptive field surround of ganglion cells in the rabbit retina. Brain Res. 414: 182-186.

Mangel, S. C., M. Ariel, and J. E. Dowling (1985) Effects of acidic amino acid antagonists upon the spectral responses of carp horizontal cells: Circuitry of the outer retina. J. Neurosci. 5: 2839-2850.

Masland, R. H., and A. Ames (1976) Responses to acetylcholine of ganglion cells in an isolated mammalian retina. J. Neurophysiol. 39: 1220-1235.

Miller, R. F., and R. F. Dacheux (1976) Synaptic organization and ionic basis of on and off channels in mudpuppy retina. I. Intracellular analysis of chloride-sensitive electrogenic properties of receptors, horizontal cells, bipolar cells, and amacrine cells. J. Gen. Physiol. 67: 639-659.

Mitarai, G., T. Asano, and Y. Miyake (1974) Identification of five types of S-potentials and their corresponding generating sites in the horizontal cells of the carp retina. Jpn. J. Ophthalmol. 18: 161-176.

Naka, K. I. (1972) The cells horizontal cells talk to. Vision Res. 22: 653-660.

Naka, K. I., and P. Witkovsky (1972) Dogfish ganglion cell discharge resulting from extrinsic polarization of the horizontal cells. J. Physiol. (I ond.) 22.3: 449-460.

Negishi, K., and B. Drujan (1978) Effects of catecholamines on the horizontal cell membrane potential in the fish retina. Sensory Processing 2: 388-395.

O'Bryan, P. M. (1973) Properties of the depolarizing synaptic potential evoked by peripheral illumination in cones of the turtle retina. $J$. Physiol. (Lond.) 235: 207-233.

Raynauld, J. P., J. R. Laviolette, and H. J. Wagner (1979) Goldfish retina: A correlate between cone activity and morphology of the horizontal cell in cone pedicules. Science 204: 1436-1438.

Rodieck, R. W., and W. A. H. Rushton (1976) Cancellation of rod signals by cones, and cone signals by rods in the cat retina. J. Physiol. (Lond.) 254: 775-785.

Teranishi, T., K. Negishi, and S. Kato (1983) Dopamine modulates S-potential amplitude and dye-coupling between external horizontal cells in the carp retina. Nature $301: 243-246$.

Teranishi, T., K. Negishi, and S. Kato (1984) Regulatory effect of dopamine on spatial properties of horizontal cells in carp retina. J. Neurosci. 4: 1271-1280.

Tornqvist, K., X.-L. Yang, and J. E. Dowling (1988) Modulation of cone horizontal cell activity in the teleost fish retina. III. Effects of prolonged darkness and dopamine on electrical coupling between horizontal cells. J. Neurosci. 8: 2279-2288.

Werblin, F. S., and J. E. Dowling (1969) Organization of the retina of the mudpuppy, Necturus maculosis. II. Intracellular recording. $J$. Neurophysiol. 32: 339-355.

Wu, S. M., and J. E. Dowling (1980) Effects of GABA and glycine on the distal cells of the cyprinid retina. Brain Res. 199: 401-414.

Yang, X.-L., M. Tauchi, and A. Kaneko (1982a) Effects of prolonged dark adaptation on the sensitivity of L-type external horizontal cells. J. Physiol. Soc. Jpn. 44: 421.

Yang, X.-L., M. Tauchi, and A. Kaneko (1982b) Quantitative analysis of photoreceptor inputs to external horizontal cells in the goldfish retina. Jpn. J. Physiol. 32: 399-420.

Yang, X.-L., K. Tornqvist, and J. E. Dowling (1988) Modulation of cone horizontal cell activity in the teleost fish retina. II. Role of interplexiform cells and dopamine in regulating light responsiveness. J. Neurosci. 8: 2269-2278.

Zucker, C. L., and J. E. Dowling (1987) Centrifugal fibers synapse on interplexiform cells in teleost retina. Nature 330: 166-168. 